\title{
Singapore Pie in Global Chinese Education: Inheritance and Innovation in Chinese Literature Education in Singapore
}

\author{
LI Jia, QU Jing-yi \\ Nanyang Technological University, Singapore
}

\begin{abstract}
Singapore's Chinese literature education has continuously evolved and advanced over the years, forming a unique style in global Chinese education, which can be described as: "Singapore pie". Through its bilingual policy, the Singapore government has been committed to creating a pool of bicultural talents, by supplementing the teaching of Chinese language with classes on Chinese literature and culture. This thesis seeks to understand the pros and cons of Chinese literature education in Singapore by analysing its development over the years. The teaching of Chinese literature began with the first wave of Chinese migration to Nanyang in the 19th century, and from there, it went through three phases of development: relocation, adjustment, and burgeoning.
\end{abstract}

Keywords: teaching Chinese literature in Singapore, Chinese literature, Nanyang characteristics, teaching Chinese as secondary language

\section{Introduction}

In 1990, renowned Singaporean songwriter, Liang Wern Fook (梁文福), composed a ballad titled “Singapore Pie" (Xinjiapopai 新加坡派). In its final verse, he wrote: “While the others send us apple pies, we can create our own Singapore pie. Now the others are immigrating here, who doesn't love the Singapore brand?"1 This "Singapore brand", "Singapore style", or "Singapore model", has served as a reference for many countries politically, economically, etc. In the area of global Chinese education, Singapore has also taken up a special position as it is the only country with a Chinese majority population outside China. Through its bilingual policy, the Singapore government has been committed to creating a pool of bicultural talents, by supplementing the teaching of Chinese language with classes on Chinese literature and culture. This thesis seeks to present the pros and cons of Singapore's Chinese literature education, by narrating and analysing its uniquely Singapore development.

\section{Relocating South: Early Chinese Literature Education}

The first wave of large-scale Chinese immigration to Singapore took place in the 19th century. Nostalgia and love for their homeland motivated this group of predominantly southern Chinese immigrants to set up private academies that educated youths in their respective dialect. These academies functioned very much like

LI Jia, assistant professor, Ph.D., Asian Languages and Cultures, National Institute of Education, Nanyang Technological University.

QU Jing-yi, assistant professor, Ph.D., Chinese Department, Nanyang Technological University.

1 Liang Wern Fook, Singapore Pie Album. (1990). "Pie" and "brand" are both pronounced as pai in Mandarin, rhyming and functioning as puns. 
those in China that employed traditional Chinese teaching methods and syllabuses. Singapore's first such Chinese academy, Chongwen Ge (崇文閣), was set up in the 29th year of Emperor Daoguang's reign (1849). This was recorded in the "Stone Tablet in Memory of the Founding of Chongwen Ge" (Xingjian chongwengebeiji 興建崇文閣碑記):

From here, the student becomes a gentleman, by studying Confucian classics and understanding Confucian values. [Which develops the student's] composure and moral character, nurturing his innate goodness, turning an ignorant into a literate, turning the boorish into the refined. With such benefits for society, how can one not show humble support.

從茲成人小子, 讀孔孟之書, 究洛閩之奧, 優柔德性, 培養天真, 化固陃為文章, 變鄙俗為風雅, 則斯閣之建, 其有裨益于世道人心者豈鮮淺哉。2

This inscription made it clear that Chongwen Ge's mission was to impart Confucian thought. The same point was made in the inscription for the founding of Cuiying Academy (萃英書院) in 1854:

Consequently, the idea of establishing an academy burgeoned in Mr Chen Junchuan's mind, he donated money for the purchase of land for the school building, with hopes that the school will educate all students into talents, regardless of whether they are rich or poor. Thereafter, [with 11 others joining], the 12 of them sponsored the school's construction, and many other followed suit in this wonderful deed. Subsequently, a date was chosen for the commencement of construction at the purchased land. The central building was a shrine dedicated to Wenchang Dijun and Ziyang Fuzi, which also doubled as the academy... In future, refined gentlemen will walk the streets, with every person understanding the Confucian Way, turning an uncivilised region into one of propriety and righteousness. These will be seen as the contributions of Mr Chen Junchuan and the others.

於是，陳君巨川存興賢勸學之盛心，捐金買地願充為黨序之基，欲以造就諸俊秀，無論貧富子弟鹹使之入學， 故複舉十二同人共彉董建，且又繼派諸君以樂成其美，擇日興工，就地萄築，中建一祠為書院，崇祀文昌帝君、紫 陽夫子神位。……他日斯文蔚起, 人人知周孔之道, 使荒陬避域, 化為禮義之邦, 是皆巨川君與時而君以及都人士 之所貽也。3

Since her independence in 1965, Singapore's Chinese language syllabus has been deeply influenced by China, Taiwan, Hong Kong, and even Malaysia. Texts chosen were mainly a simplified Chinese literary history and selected literary works published in China, with Chinese Literary Selections (Zhonghuawenxuan 中華文 選) being the most popular. This series of eight books was published by Zhonghua Book Company in 1937. It was later adopted as Hong Kong middle school's Chinese language textbook in the 1940s, before making its way to Nanyang. This series comprised of mainly post-May Fourth Movement vernacular Chinese literary works, and a smaller percentage belonged to international works translated into Chinese, and selections from The Anthology of Essays (Guwenguanzhi 古文觀止), etc. The large number of vernacular Chinese literature selection was reflected in its sizeable collection of LU Xun's (魯迅) works: Autumn Night (Qiuye 秋夜), A Good Story (Hao de gushi 好的故事), Snow (Xue 雪), Kite (Fengzheng 風箏), The Comedy of the Ducks (Ya de xiju 鴨的喜劇), Hometown (Guxiang 故鄉), and some of his translations-Reading Methods (Dushu de fangfa 讀書的方法), For the Young (Yu youxiaozhe 與幼小者), etc. This anthology of literary works left a great impact on Singapore Chinese education; its influence was seen in all Chinese textbooks that were edited and published locally since then.

\footnotetext{
${ }^{2}$ Chen Jing-he (陳荊和) \& Chen Yu-song (陳育嵩). (1970). 新加坡華文碑銘錄 (Chinese inscriptions in Singapore) (p. 283). Hong Kong: Hong Kong Chinese University Press.

3 Ibid., pp. 291-292.
} 
With the "dissemination of Western knowledge" (xixuedongjian 西學東漸) into late Qing China, the imperial court decided to reform its education system between 1902 and 1904. This resulted in the implementation of the "Renyin-Kuimao Education System" (Renyin-kuimaoxuezhi 壬寅一癸卯學制), where Chinese literature was made an independent subject — to distinguish it from the study of Western literature. Although "Chinese literature" at this point of time in history was not confined to the study of literary texts, it has at least been separated from the traditional studies of Confucian classics. The impact of these reforms was felt as far as Singapore, where English literature has always been an independent subject under the Cambridge examinations system. In the 1960s, Chinese literature was made a subject, separating "language" from "literature" in the Chinese curriculum, allowing language classes to focus on language proficiency, while literature classes could cultivate students' understanding and appreciation of Chinese culture. It is worth noting that "Chinese literature" as a subject title revealed Singaporean Chinese's nostalgia for their "motherland". In terms of teaching materials, nothing changed - textbooks were still made up of selected literary works and a simplified Chinese literary history. An Introduction to the History of Chinese Literature (Zhongguowenxueshichubu 中國文學史初步) by Hong Kong academic FENG Ming-zhi (馮明之) was usually the core textbook, supplemented by LIU Da-jie's (劉大杰) The Development History of Chinese Literature (Zhongguowenxuefazhanshi 中國文學發展史) and DING Si-wen's (丁思文) A Brief History of Chinese Literature (Zhongguowenxueshihua 中國文學史話), etc. This choice of textbooks reflected a conscious effort of bringing traditional Chinese literary classics into Singapore classrooms, enabling students to understand and appreciate Chinese literature, as well as to cultivate a group of able and interested students who might want to pursue further studies in the subject. This line of thought was viable at that time when Chinese was the first language of most students, and these students were more or less emotionally attached to China. Therefore, the literature syllabus was well-received as it satisfied the first-generation immigrants' nostalgia for their motherland.

\section{Localising Literature Education: An Awkward Adjustment}

Beginning in the 1970s, Singapore edited and published her own Chinese literature textbooks. The first was written based on Liu Dajie's The Development History of Chinese Literature and published by Singapore Education Press in 1976. Following that, in 1982, Meiya Book Company published a series of literature textbooks titled Supplementary Reader for Secondary Schools (Zhongxuebuchongbuben 中學補充讀本), which included “A Selection of Tang and Song Poetry” (Tang Song shicixuan 唐宋詩詞選), “A Selection of Classical Prose” (Wenyanwenxuan 文 言 文 選 ), “A Selection of Modern Fiction” (Xiandaiduanpianxiaoshuoxuan 現代短篇小說選), “A Selection of Modern Poems” (Xiandaishixuan 現代詩 選), and “A Selection of Modern Drama” (Xiandaixijuxuan 現代戲劇選). These laid the foundation for Singapore secondary school's Chinese literature syllabus, specifically:

(1) The study of literary history as its core;

(2) The study of five genres of literary works - poetry, ci, prose, fiction, drama — as its breath.

The publication of the textbooks mentioned marked the starting point in Singapore's quest to develop its own teaching materials. Interestingly, after years of syllabus changes, the key rationale and content have remained more or less the same. Take the content of "A Selection of Classical Prose" for example, it included four Pre-Qin fables, five conversations from Analects (Lunyu 論語), selections from Historical Records (Shiji 史記), and works by renowned Tang and Song writers: TAO Yuan-ming (陶淵明), HAN Yu (韓愈), BAI Ju-yi 
(白居易), LIU Zong-yuan (柳宗元), SU Shi (蘇軾), WANG An-shi (王安石), ZHOU Dun-yi (周敦頣), etc. When this is compared to the latest 2013 Syllabus Literature in Chinese Secondary, one would not miss the similarities. The new syllabus' choice of classical prose included: three Pre-Qin fables, selections from Historical Records, "The Peach Blossom Spring” by TAO Yuan-ming, and works by LIU Zong-yuan, ZHOU Dun-yi, YUAN Hong-dao (袁宏道), and PU Song-ling (蒲松齡). ${ }^{4}$ Other than extending the selection of prose to Ming and Qing period, the rationale and framework of the syllabus have largely remained intact after 30 years of reforms. As for Analects, it is just moved to the $\mathrm{H} 3$ syllabus.

It is worth noting that modern drama has always been an important component of Singapore's Chinese literature syllabus. This could be seen from Meiya Book Company publishing "A Selection of Modern Drama", which included works such as DING Xi-lin's (丁西林) Three Dollars in National Currency (Sankuaiqianguobi 三塊錢國幣), GU Jian-chen's (穀劍鹿) Cold Rice (Lengfan 冷飯), and another piece by Singapore's theatre pioneer, LIN Chen 林晨, titled The Woman Who Broke the Glass (Dapojingzi de nuren 打破鏡子的女人). ${ }^{5}$

Following that, in the 1980s, Singapore's Ministry of Education implemented a new secondary school Chinese literature syllabus. A new set of textbooks by Ong Yong Peng (王永炳) and Tan Ik Ching (陳益清) were published in view of the change: A Selected Reading of Literature (Wenxuezuopinxuandu 文學作品選讀) in 1983 and A Basic Knowledge of Chinese Literature (Zhonghuawenxuejibenzhishi 中華文學基本知識) in 1985. There were some additional content in this new literature syllabus: For classical literature, literary pieces from Chinese mythology, Book of Songs (Shijing 詩經), and Songs of Chu (Chuci 楚辭) were added. For modern literature, new contents included New Literature Movement, modern poetry, modern drama, modern prose, modern fiction, etc. ${ }^{6}$ At this point of time, students from English-speaking families had swelled to $40 \%$ of the cohort. In other words, close to half of the learning cohort had English as their first language, and there was a general decline in the standard of Chinese language. Therefore, it was no surprise that students found the new syllabus challenging.

Another round of syllabus revision took place in the late 1990s, where a similar set of textbooks by Tan Ik Ching and CHEN An-de (陳安德) was published. They were the 1997 version of A Basic Knowledge of Chinese Literature and 1998 version of $A$ Selected Reading of Literature. Surprisingly, the syllabus was not simplified but instead made more demanding. Contents included Books of Songs, Songs of Chu, Pre-Qin prose, Han poetry, Tang poetry, Han prose, Five Dynasties and Ten Kingdoms and Song $c i$, Yuan drama, Ming-Qing fiction, profiles of modern literature authors, etc. These look a lot more like the syllabus of an undergraduate course on the history of Chinese literature, than what is required of a secondary school student. Some content might have been removed from this round of syllabus revision, but it was clearly a lopsided one, as reductions were only made in modern literature, leaving classical literature untouched. This could be seen when comparing the new syllabus to that of 1980: Modern fiction was reduced from five to three stories, and modern poems were halved from eight to four, while no changes were made to classical literature. ${ }^{7}$ In simple terms,

\footnotetext{
${ }^{4}$ Division of Curriculum Planning and Development, Ministry of Education, Singapore. "2013 Syllabus Literature in Chinese Secondary". $\quad$ See https://www.moe.gov.sg/docs/default-source/document/education/syllabuses/mother-tongue-languages/files/2013-literature-in-chi nese-syllabus-secondary.pdf.

${ }^{5}$ QIN Jue (秦玨). (2013). Research of the Chinese literary textbooks in Singapore secondary schools (新加坡中學華文文學教材 研究) (p. 9) (Master's thesis, National Institute of Education, Nanyang Technological University of Singapore).

6 Ibid., p. 10.

7 Ibid., pp. 11-12.
} 
this revision enhanced the classical literature content at the expense of modern literature. It is evident that the new syllabus failed to take into consideration the general decline in Chinese standards amongst students, and instead complicated the issue by implementing more demanding content. This shows that Singapore's Chinese education was at a conservative stage and struggling to find its footing.

In 2004, the Ministry of Education commissioned a special review committee tasked to review existing primary and secondary school's Chinese curriculum. It is important to note that years of implementing the bilingual policy has led to an ever-growing number of students from English-speaking families. They generally find the Chinese language a demanding subject and have lost interest in the language after sitting through Chinese classes from primary to secondary school. One notable change from the 2004 review was the renaming of Chinese Literature as Literature in Chinese. This rearrangement of word order is significant as it showed the development of Singaporean Chinese's sense of identity. Unfortunately, this was not reflected in the 2006 Syllabus Literature in Chinese Secondary, ${ }^{8}$ where students were still assessed by their understanding of the "development of major genres" from Pre-Qin to around May Fourth New Culture Movement, with reference to the four major genres of poetry, prose, fiction, and drama. In addition, there were specific requirements for each genre of study:

Poetry and ci: (1) Book of Songs' origin, content-feng (airs), ya (odes), song (hymns) - and characteristics - fu, bi, xing; (2) Songs of Chu's origin, content, and characteristics; and its central poet, QU Yuan's (屈原) life, thought, literary style, and role in literary history; (3) Han yuefu's (樂府詩) content and features; (4) Han's five-character quatrain' system and features; (5) Poetry composition during Jian'an period and its features; (6) Wei-Jin's pastoral poems and landscape poems, BAO Zhao's (鮑照) five- and seven-character quatrain and its impact on Tang poetry. Features of Yongming (永明體) poetry and its impact on Tang poetry; (7) Overview of the development and characteristics of Tang poetry; and style and works of representative poets; (8) Song ci's origin, development, and features. Poetic styles and works of representative $c i$ writers during the Five Dynasties, and Southern and Northern Song; (9) Yuan drama's origin, development, and characteristics; and (10) May Fourth New Literary Movement's impact on the development of poetry. The development and characteristics of modern poetry.

Prose: (1) Pre-Qin prose's development and characteristics; and content and features of Analects, Mencius (Mengzi 孟子), Zhuangzi (莊子), and Commentary of Zuo (Zuozhuan 左傳); (2) Han prose-biography, Historical Records' features; (3) Factors leading to the rise of Tang's guwen (archaic-style prose) movement, its key advocates'一HAN Yu (韓愈) and LIU Zong-yuan (柳宗元) - literary ideas and its impact; (4) Factors leading to the rise of Song's guwen movement, its key advocate's_-Ouyang Xiu (歐陽修)—literary ideas and its impact; (5) Ming-Qing prose's key features; and (6) May Fourth New Literary Movement's impact on the development of prose. The development and characteristics of vernacular prose.

Fiction: (1) Ancient mythology's content, features, and its impact; (2) Wei-Jin short stories' content, features, and its impact; (3) Tang legends' content, features, and its impact; (4) Song-Yuan scripts' content, features, and its impact; (5) Ming novels' development overview; and characteristics of chapter-novels. Contents and characteristics of Water Margin (Shuihuzhuan 水澈傳), Three Kingdoms (Sanguoyanyi 三國演 義), Journey to the West (Xiyouji 西遊記), and The Plum in the Golden Vase (Jinpinmei 金瓶梅); (6) Qing

\footnotetext{
${ }^{8}$ Division of Curriculum Planning and Development, Ministry of Education, Singapore. "2006 Syllabus Literature in Chinese Secondary". See https:/www.moe.gov.sg/docs/default-source/document/education/syllabuses/mother-tongue-languages/files/literature-in-chinese-s econdary.pdf.
} 
novels' development overview-including chapter-novels and short stories. Contents and characteristics of The Scholars (Ruilinwaishi 儒林外史), Dream of Red Chamber (Hongloumeng 紅樓夢), Strange Tales From a Chinese Studio (Liaozhaizhiyi 聊齊志異); (7) Late Qing novel of denunciation's (qianzexiaoshuo 譴責小說) content and characteristics; and (8) May Fourth New Literary Movement's impact on the development of fiction. The development and characteristics of modern fiction. The life and literary achievements of LU Xun.

Drama: (1) Factors leading to the rise Yuan Drama and Southern Opera, its features, and development overview - structure, tune, lyrics, lines, actions, and roles; (2) Factors leading to the rise of Ming legend, and its factors; (3) Factors leading to the rise of Qing local drama, and its factors; and (4) The evolution of Chinese drama under the influence of Western drama, including modern genres of Chinese drama. Works by CAO Yu (曹禺).

The implementation of this new syllabus pushed the learning of Chinese literature to its extremes. Literature in Chinese is an elective subject offered to secondary three and four students, and they are expected to complete the course within two years. If this syllabus was challenging for China and Taiwan students-with Chinese as their first language - it would be arduous for Singapore students who have been brought up in English-speaking families. This led to the fall in the number of candidates taking Literature in Chinese as a subject at O Levels, in 2012, the number of candidates was half of that a decade ago. ${ }^{9}$

Besides Chinese literary history, the 2006 syllabus also made quite a few changes to its selection of literary works. In the section on "Classical Prose", there were six selections: "The Debate of Hao-Liang" (Hao Liang zhibian 濠梁之辯) from Zhuangzi; “The Jesters” (Huajiliezhuan 滑稽列傳) from Historical Records; “Explanation of the Horse” (Zashuo Mashuo 雜說・馬說) by HAN Yu; “The Love for Lotus" (Ailianshuo 愛 蓮說) by ZHOU Dun-yi; “Looking at the Snow in the Mid-lake Pavilion” (Huxintingkanxue 湖心亭看雪) by ZHANG Dai (張岱); and “To Learn” by PENG Duan-shu (彭端淑). Evidently, this selection had its focus on discursive prose conveying moral teachings. The rationale for selecting these proses was to emphasise the practical uses of prose and to instil moral values. For the section of Tang poetry, works chosen include: Wang Wei's (王維) “Song of Wei City” (Wei Cheng qu 渭城曲); Li Bai's (李白) “Setting Off Early from Baidi City” (Zaofa Baidi Cheng 早發白帝城); DU Fu's (杜甫) “Upon Hearing the Recovering of Henan and Hebei” (Wen guanjunshou Henan Hebei 聞官軍收河南河北); ZHANG Ji’s (張繼) “Maple Bridge Night Mooring” (Fengqiaoyepa 楓橋夜泊); and DU Mu's (杜牧) “Parting (II)” (Zengbieqi'er 贈別[其二]). Each of these poems was labelled according to their poetic format: seven-character quatrain, seven-character regular verse, five-character regular verse, etc. Cleary, the focus was on introducing the two categories of ancient- and modern-style poetry, but this inevitably led to a less than comprehensive selection of poems in terms of time period. For instance, there were an equal number of poems from Mid- and High-Tang period, but unfortunately, none from Early-Tang. As for the section on "Modern and Contemporary Fiction", works included: Bi Shumin’s (畢淑敏) Apple Core (Pinguo he 蘋果核); Xi Ni Er's (希尼爾) The Earnest Mask (Renzhenmianju 認真面具); Duo La's (朵拉) Mirror on the Sidewalk (Xingrendaoshang de jingzi 行人道上的鏡子); RU Zhi-juan's (茹志娟) Lilies (Baihehua 百合花); Hwang Chun-ming's (黃春明) J'aime Mary (Wo ai Mali 我愛 瑪麗); and parts of JIN Yong's (金庸) The Legend of the Condor Heroes (Shediaoyingxiongzhuan 射雕英雄 傳). Works chosen were by authors from China, Hong Kong, Taiwan, Singapore, and Malaysia, reflecting a

\footnotetext{
${ }^{9}$ CHEN Qiu-hua (陳秋華). “Xiuduhuawenwenxuerenshuxiajiang” (修讀華文文學人數下降). Lianhezaobao, May 31, 2013. See http://www.zaobao.com.sg/realtime/singapore/story20130525-208530.
} 
distinctly regional flavour. “Modern Poetry” section included: XU Zhi-mo’s (徐志摩) “Accidental” (Ouran 偶 然); Liang Wern Fook’s “Echo” (Huisheng 回聲); WEN Yi-duo's (聞一多) “Dead Water” (Sishui 死水); SHU Ting's (舒婷) “To the Oak Tree” (Zhixiangshu 致橡樹); YU Guang-zhong’s (余光中) “Waiting for You, I'm in the Rain” (Dengni, zaiyuzhong 等你, 在雨中); WU Sheng's (㕦晟) Earth ( $T u$ 土); LI Nan’s (李男) “Blackout” (Tingdian 停電); and Wong Yoon Wah’s (王潤華) “Shadow Show” (Piyingxi 皮影戲). Totalling eight poems, this selection was double the number of modern poetry in the previous syllabus. In terms of nationality, besides works by Chinese (including Taiwan) poets, there were poems by two Singaporean poets. In terms of poetic styles, there was a comprehensive inclusion of metrical (gelupai 格律派), nativist (xiangtupai 鄉土派), modernist (xiandaipai 現代派), obscure (menglongshipai 朦朧詩派), etc. However, Singapore students had difficulty understanding poems like "Dead Water" and "Shadow Show", let alone analysing imageries which they cannot relate to, such as "earth", "shadow", "blackout", "oak tree", etc. It is thus no surprise that the teaching outcomes were less than satisfactory.

A brief look at the latest syllabus revision revealed some key features: First, excessive emphasis was placed on literary history content, which showed a complete lack of understanding of students' abilities. This resulted in students engaging in rote learning, and finding the subject a huge burden and uninteresting. Second, in terms of literary works selection, there was a decrease in classical literature content and an increase in modern literature content. The former was reduced from 23 literary works to 28 , while the latter was increased from 7 to 14 . This meant that students might have fewer issues understanding the new texts. Third, the modern drama genre was an important and distinctive feature of Singapore's literature syllabus, but it was surprisingly removed and placed in the A Level $\mathrm{H} 2$ syllabus. Clearly, literature education was still finding its footing; and a syllabus that focuses on political and moral education, and the practicality of literary works, would definitely reduce the charm of literature. Transplanting the old into new soil is like taking a fish out of water, Singapore was still going through the awkward localisation phase of Chinese literature education.

\section{Blossoming Orchid: Chinese Literature in Nanyang Colours}

In 2010, the Ministry of Education set up the Mother Tongue Languages Review Committee to review Singapore's Chinese syllabus and curriculum, which led to the eventual birth of 2013 Syllabus Literature in Chinese Secondary. This can be considered a milestone in the reform of Singapore's Chinese literature education. The most significant change in the latest syllabus is the removal of Chinese literary history as a core assessment criterion, which means the mainstay of literature syllabus for over 30 years will no longer make an appearance in textbooks. Let's compare the requirements of the 2006 and 2013 syllabus:

The development of four literature genres - poetry, prose, fiction, and drama-from the period of Pre-Qin to around May Fourth New Literature Movement. They must also master basic skills in analysing and appreciating classical, modern, and contemporary literature. ${ }^{10}$

Students doing this literature course should acquire a certain level appreciation and analysis skills, and an understanding of the background and artistic features of every literary work, in order to have a basic appreciation of a literary work, and the capacity to interpret its content and literary features. ${ }^{11}$

\footnotetext{
10 Division of Curriculum Planning and Development, Ministry of Education, Singapore. "2006 Syllabus Literature in Chinese Secondary".

11 Division of Curriculum Planning and Development, Ministry of Education, Singapore. "2013 Syllabus Literature in Chinese Secondary".
} 
The former focused on the historical development of the four literary genres while expecting students to master basic skills in analysing and appreciating literature. But with limited curriculum time to complete the heavy workload, students can only resort to rote learning in their preparation for examinations. In contrast, the knowledge aspect is removed in the 2013 syllabus, where the focus has shifted to the cultivation of analytics skills, and the understanding and appreciation of literary works. This is certainly a wise move in a learning environment where Chinese is the second language of most students. In addition, the study of four major literary genres has remained unchanged between the 2006 and 2013 syllabus, but there is a huge change in the selection of literary works from each genre.

Classical prose: The selection of classical prose begins similarly with Pre-Qin fables, they are "Who Retreats Fifty Mocks Who Retreats a Hundred” (Wushibuxiaobaibu 五十步笑百步) from Mencius; “Sighing to the Seas" (Wangyangxingtan 望洋興嘆) from Zhuangzi; and “The Jewellery Box” (Maidu huanzhu 買櫝還 珠) from Hanfeizi (韓非子). This is again followed by Sima Qian's (司馬遷) Historical Records, but the piece selected is “Jingke Assassinating Emperor Qin” (Jingke ci Qin 荊柯刺秦) of the “Assassins Section” (Cikeliezhuan 刺客列傳). These are supplemented by prose of later dynasties, namely, “The Peach Blossom Spring” by TAO Yuan-ming; “Travels of Little Stone Pond” (Xiaoshitanji 小石潭記) by LIU Zong-yuan; and "The Love for Lotus" by ZHOU Dun-yi. These are not entirely new additions to the syllabus as they have been part of the 1982 literature syllabus. The only new contents are "Record of my Excursion in Manjing" (Manjingyouji 滿井遊記) by YUAN Hong-dao, and “Wolf II" (Lang san ze II 狼三則[之二]) by PU Song-ling. Comparing the two syllabuses, it can be seen that the new syllabus has the following features: (1) an increase in the number of proses; (2) The 2006 prose selected are mainly discursive prose, while the 2013's selection focuses on travel pieces. The latter's selection is better catered to the students' learning abilities, and its artistic value and applicability to everyday life are much better compared to the discursive prose selected in 2006; and (3) The prose is generally narrative, bringing across ideas through a simple plot, making it more interesting and enhancing its readability.

Poetry and $c i$ : 15 are included in the new syllabus, where five of these are new additions, namely: "Guanju" (關㫿) from Book of Songs; “Far in the Skies is the Draught Ox Star” (Tiaotiaoqianjiuxing 迢迢牽牛星) of “Nineteen Old Poems” (Gushishijiushou 古詩十九首); “The Ballad of Mulan” (Mulan ci 木蘭辭); and “Tianjingsha: Autumn Thoughts” (Tianjingshaqiusi 天淨沙・秋思).This increase in the number of poems and $c i$ is to fill the gap left behind by the removal of literary history content, as it is hoped that students can gain an understanding of literary history through studying classics from different time periods. Comparing the Tang-Song $c i$ selected in 2006 and 2013 syllabus, it will reveal the following characteristics of the 2013 syllabus: (1) a selection of representative works from four stages of Tang history; (2) representative works from both pastoral and frontier poems (biansaishi 邊塞詩); and (3) compared to 2006's large selection of euphemistic ci (wanyue ci 婉約詞), 2013's selection has a more balanced choice of euphemistic and unconstrained $c i$ (haofang $c i$ 豪放詞). It can be observed from the above analysis that the new syllabus has a more comprehensive understanding of literary history, and its selection of works is representative of the respective historical period.

Modern and Contemporary Fiction: Selected works include LU Xun's Kong Yiji (孔乙己); Hwang Chun-ming's Fish ( $Y u$ 魚); TIE Ning's (鐵凝) Oh! Sweet Snow (O, xiangxue 哦, 香雪); WANG Zeng-qi's (汪曾祺) Little Hands Chen (Chen xiaoshou 陳小手); LI Rui's (李銳) Electing Thieves (Xuanzei 選賊); Liu 
Su's 流蘇 (Guimixinqiao 鬼迷心憿); Xi Ni Er's The Earnest Mask; and LI Zi-shu's (黎紫書) The Reunion Dinner (Chunmanqiankun 春滿乾坤). These are all new contents in the 2013 syllabus with the exception of Xi Ni Er's The Earnest Mask. Comparing the two syllabi, it can be observed that: (1) There is an increase of two short stories; (2) a greater proportion of works by Malaysian Chinese authors, totalling three short stories; and (3) a greater diversity of content from China authors, including classics and non-classics. But unfortunately, JIN Yong's swordsman fiction is removed from the syllabus following feedback from teachers and students reflecting the difficulties faced in teaching and learning it. This bold attempt in literature teaching regrettably ended hastily.

Modern and Contemporary Poetry: Works selected include XU Zhi-mo's "Accidental"; YU Guang-zhong's "Folk Song” (Minge 民歌); DAN Ying's (淡瑩) "Inside and Outside My Umbrella" (Sanneisanwai 傘內傘外); XI Mu-rong's (席慕容) “A Flowering Tree” (Yikekaihua de shu 一棵開花的樹); SHU Ting’s (舒婷) “Yearning” (Sinian 思念); and Liang Wern Fook’s “Echo”. The majority of these works are new additions, except "Accidental" and "Echo", but these additions did not bring with it greater diversity in literary themes. These poems revolve around the theme of "love", while this might interest secondary school students, it inevitably limited the student's exposure to different poetic themes.

In conclusion, the new Literature in Chinese syllabus that was released in 2013 is a significant breakthrough in literature education reform. It brought the teaching objectives and priorities in line with the characteristics of "literature", and emphasised the mastering of skills in appreciating the emotional and artistic aspect of literature. The elimination of literary history content from the syllabus is an appropriate move to reduce students' workload. In terms of literary works selected, they are generally classics and representative in their respective area. In the section on classical literature, for instance, works selected are classics representative of its specific time period and genre. Through the study of these works, students can form a more organic understanding of Chinese literary history and culture, and at the same time, appreciate this intangible Chinese heritage. In the section of modern and contemporary literature, there is a greater presence of works with Nanyang and regional flavour, and the poems and fiction was chosen from this period covered a multitude of content and styles, thereby creating a distinctive Singapore literature education.

\section{Conclusion}

Orchids are called lanhua (蘭花) in China; through transplanting, it was brought to Nanyang and renamed hujihua (胡姬花). Not only did it acclimatise under careful cultivation, it gave birth to the resilient, elegant, and poised Vanda "Miss Joaquim"-Singapore's national flower-thriving on this land of paradise. This is similar to what Singapore went through in its development of literature in Chinese education: Beginning with a yearning for "motherland" like how "a northern horse attaches to the northern breeze, and a southern bird clings to a southern tree". Before moving on to creating its own teaching materials in the 1970s, but this was more of transplanting the old into new soil, and like a fish out of water, it was an awkward localisation process. Following years of reflections and reviews, it begins to find its footing and understand the purpose of having a course on Chinese literature. With a better grasp of Chinese and Singapore-Malaysia literature, it is slowly opening up a unique path of literature education. Despite it being a long journey, we are confident in cultivating a far stronger and gorgeous orchid in the near future. 


\section{References}

CHEN, J. H., \& CHEN, Y. S. (1970). 新加坡華文碑銘錄 (Chinese inscriptions in Singapore). Hong Kong: Hong Kong Chinese University Press.

CHEN, Q. H. (2016). 修讀華文文學人數下降 (The student number of choosing to study Chinese literature is declining). Lianhezaobao. Retrieved May 31, 2013 from http://www.zaobao.com.sg/realtime/singapore/story20130525-208530

Division of Curriculum Planning and Development, Ministry of Education, Singapore. (2006). 2006 syllabus literature in Chinese
Secondary.
Retrieved
July
15
2014
from

https://www.moe.gov.sg/docs/default-source/document/education/syllabuses/mother-tongue-languages/files/literature-in-chin ese-secondary.pdf

Division of Curriculum Planning and Development, Ministry of Education, Singapore. (2013). 2013 syllabus literature in Chinese $\begin{array}{lllll}\text { secondary. } & \text { Retrieved } & \text { July } & 15, & \text { from }\end{array}$ https://www.moe.gov.sg/docs/default-source/document/education/syllabuses/mother-tongue-languages/files/2013-literature-i n-chinese-syllabus-secondary.pdf

QIN, J. (2013). 新加坡中學華文文學教材研究 (Research of the Chinese literary textbooks in Singapore secondary schools) (Master's thesis, National Institute of Education, Nanyang Technological University of Singapore). 